\title{
Transient obturator neuropathy due to local anesthesia during transobturator sling placement
}

\author{
Amy J. Park • John M. Fisch • Mark D. Walters
}

Published online: 2 September 2008

(C) The International Urogynecological Association 2008

Erratum to: Int Urogynecol J

DOI 10.1007/s00192-008-0683-y

The second author's was rendered wrongly. His correct name is John M. Fisch.

The online version of the original article can be found at http://dx.doi. org/10.1007/s00192-008-0683-y.

A. J. Park $(\bowtie) \cdot$ M. D. Walters

Cleveland Clinic,

Section of Female Pelvic Medicine and Reconstructive Pelvic,

Surgery, Department of Gynecology and Obstetrics,

9500 Euclid Ave Desk A81,

Cleveland, OH 44195, USA

e-mail: parka@ccf.org

J. M. Fisch

Department of Obstetrics and Gynecology,

Magee Women's Hospital,

Pittsburgh, PA, USA 